\title{
Absent Words, Present Person
}

Joan Yujae Lee, $A B$

Neurology ${ }^{\circledR}$ 2021;96:908-910. doi:10.1212/WNL.0000000000011758
Correspondence

Dr. Lee

joan.lee29@gmail.com

It's some summer month when the sun is warming the neurocritical care unit's pale, frigid rooms before morning rounds. Scattered shouts of the NIH Stroke Scale prompts echo throughout the unit. Disproportion between the call and response is typical, as many of the patients have emerged from strokes with moderate to severe expressive aphasia.

"Lift up your leg! LIFT UP YOUR LEG!"

"The aphasic patient is encouraged using urgency in the voice and pantomime, but not noxious stimulation," instruct the "Motor" prompts. Quasi-frantic commands and feebly stirring limbs slide past my senses as I hurry to meet a 74-year-old Arthur Gildea, who arrived last night with a left MCA stroke. A direct admit from the VA with no records in our hospital system, an NIHSS score greater than 25 on arrival, status-post mechanical thrombectomy with intraprocedural complications. Besides his severe neurologic deficits, an impossible goals of care discussion and difficulties for placement loom.

The curtain behind the glass doors of NSU 15 are drawn. As I approach, Arthur Gildea's form comes into view. Elderly, but not frail. I could easily picture him soaking up the sun and cracking open a cold one at a barbecue if it weren't for the 2 IV lines, Foley, and Dobhoff tethering him to his current habitat. His ruddy, freckled face and arms clash with the pale gloom around him and suggest that this may have taken place a few times this summer.

I take the stroke scale cards hanging from a hook on the door and enter.

“Good morning, Mr. Gildea?"

His eyes remain shut and his chest continues to rise and fall without interruption.

"Mr. Gildea? Are you awake?"

He opens his eyes, and as if in annoyance he shuts them with conviction.

"My name is Joan, I'm the medical student from the Stroke team. Can I ask you some questions?" He opens his eyes again to glare. "Can you tell me what month it is?"

I jump back as his left arm suddenly jerks upward. It shoots past me, pulling some lines with it as well. As he gestures wildly, an enraged expression contorts his face. Are you kidding me? This again, for the third time? What's the point? He did not need to speak a single word to make clear that, if he was able, he would have shouted some profanities. But he is silent.

I glance down at my card. Patients unable to speak because of endotracheal intubation, orotracheal trauma, severe dysarthria from any cause, language barrier, or any other problem not secondary to aphasia are given a 1 .

"Can you open and close your eyes? Can you raise your eyebrows?" He glares. "Can you show me your teeth?" He throws his arm in the air again.

I place my fingers in his large, grizzled left hand. "Can you squeeze my hand?" 
He complies and his angry eyebrows relax. However, he maintains his gaze, staring intently as he continues to squeeze my fingers rapidly.

The initial conversation with an aphasic patient is a singular experience that somehow fills 2 persons in vastly different situations with a similar mix of emotions. Mr. Gildea is fully alert, his eyes straining to say what his tongue can't retrieve. My mind tries to scrabble onto anything that he may be trying to convey in the silence. I try not to show it, but internally, I am filled with frustration and helplessness, wondering if I'm taking too much time trying to speak with someone who can't-all while wondering what is unsaid. Seeing the frustration, and later, the resignation mirrored in his eyes as we both give up.

I continue with the rest of the exam, which adds up to a marginally improved score. His right-sided hemiparesis, hemianopsia, and neglect remain, obliterating half of his world. I touch his left hand to at least give him a semblance of reassurance. He grasps my fingers and stares wildly, but his throat and mouth are motionless except for his breathing.

I take one more look at him before hurrying off. Who was he before becoming this patient?

By the next day, Mr. Gildea has established a fiery reputation for himself in the unit. His wrists are now restrained in Velcro after he pulled out 2 Dobhoffs in a row. He is again exasperated by the repetitive and seemingly purposeless exam, but perhaps his energy was spent in the excitement of yesterday afternoon, for his gestures are gentler. Though they could have just restrained his left hand, I muse as his paretic right arm slides off the bed. I click the restraint back into place anyway.

"Goals of care and disposition TBD," I type again at the end of his Assessment and Plan. A breakthrough finally comes when the nurse practitioner at the VA returns one of our calls. "He's estranged from his family, we don't know why. He was living with some woman, but she didn't visit him here. There's a phone number for a 'Mary Kelley' that might be her... how is he?" she asks in a worried voice. "He was just fine, joking and talking with us the evening before, and the next morning-" she stops.

"He's..." What do I say? "He's had a pretty big stroke. We'll be keeping an eye on him for a few days," I eke out. "Thank you so much for calling."

I walk back to NSU 15 .

"Mr. Gildea? Your nurse practitioner from the VA gave us Mary's phone number.”

His eyes narrow.
"It's the only contact number that was in your chart. Can we call her? We may need her help to arrange where you'll go when you leave the hospital."

He stares straight ahead, out the door, as some nurses wheel a machine by.

"Is there anyone else who we could call instead?"

He scowls and weakly raises his left arm in the air.

“Can we call her?"

He exhales gruffly and closes his eyes.

"Hello?" A woman answers sharply on the first ring.

“Hello? Am I speaking with Ms. Kelley?”

"Who is this?"

"My name is Joan, I'm a medical student at University Hospitals. I'm calling about Mr. Gildea.”

Silence. A very long silence. This better be the right number, I think, gritting my teeth.

“Gill-day,” she finally says.

"Excuse me?"

"It's pronounced 'Gill-day.”

“Oh. I’m sorry.”

“He's my father. I haven't seen him for 9 years. What does he want?”

"He had a pretty bad stroke, and he is with us for the time being. Your phone number was the only one that we could find."

Silence.

"We'll need your help planning his next steps once he's ready to leave the hospital."

Silence. "I can't promise anything, but I'll try to come tomorrow. I need to go."

In NSU 15, Mr. Gildea's eyes are still open, pointed at the TV. "Mr. Gill-day." His gaze shifts toward me. "Sorry we've been mispronouncing your name this whole time. I got in touch with Mary. She says she'll try to come and see you tomorrow.”

I place my hand in his, and he grasps it. "I know this is a difficult time for you, coming out of a stroke. That's why 
you're having trouble moving, feeling and seeing on your right side because of where the stroke affected your brain. It will be a slow process, but I see you getting better slowly."

It isn't untrue, as the NIHSS doesn't lie. But am I hoping too hard?

I mull over my doubts as he closes his eyes and squeezes my hand over and over again. The TV blares in the background, incongruous to the lack of words being spoken by the room's occupants. The closing and opening of his left hand is the only way that he can tangibly communicate with the outside world, or the only way out of the isolation that the stroke trapped his mind in. Perhaps it is the only way for him to proclaim his existence, that he is still here.

I still wonder how much of this is intuition, and how much of this is my projection onto the silent patient.

Mary finally arrives on the weekend, accompanied by the rest of the family unit that Mr. Gildea had split off from. His son, Matt, resembles him, towering and rotund, but with dark brown hair gelled and combed back. His ex-wife, Ginny, has also arrived, her eyes occasionally becoming misty behind her large acetate-framed glasses.

They stand by his bed, beholding him for the first time in 9 years. Matt is the first to speak. "We'll have to call his siblings and cousins. They'll all want to see him." Mary and Ginny nod, their eyes unmoving from the stuporous, bedraggled, white-haired man before them.

"Let him sleep for now, to not overwhelm him."

Ginny, Matt, and Mary are reliably coming to see him almost daily. Mr. Gildea, when awake, is usually seated with his beady eyes fixed on the television. Ginny watches him from a respectful distance, occasionally wiping her eyes as she sits with her hands folded on her lap. Matt visits most often and sits quietly by the bed. Today, he is holding his father's hand as he sleeps. Mary is the least visible of the 3 . Her gaze towards her father reflects the intense glare that I faced when I first assessed him.

Although we give them privacy, I can't help but notice that each visitor invariably sits at a palpable distance from the bedside. One party aphasic, the other at a loss for words, with the silent weight of all that can't be said to come to terms with where they are now, together, after 9 years apart. Certain human elements, however, transcend the silence. Whatever his family's grievances were against him, they remained unspoken-but they were not enough to prevent them from receiving him in his time of greatest need.

"Art always had a restless spirit," sighs Ginny as I cross paths with her leaving. "This is probably the first time that he didn't have the freedom that he lived by."

Mr. Gildea seems to be at peace-or subdued-enough for the nurses to remove his restraints and reposition him. When they do so, they unearth a small wooden cross pendant that was wedged beneath his back.

Inevitably, it finally comes time for to say goodbye, and I am hopeful. Mr. Gildea will be discharged to the VA skilled nursing facility, with his family fully involved in his care.

I enter his room for the last time as he is awaiting his transport.

"Hi, Mr. Gildea. I came to say goodbye."

His gaze is softer now, and he tilts his head forward.

"It'll be a long road, and you'll have to fight through it. But you can make progress," I tell him. "It was very nice to meet you, and I wish you luck."

I put my hand in his. He squeezes it over and over, and after a while loosens his grip.

Back in the workroom, we take his name off of the patient list. I wonder how much function his rehabilitation can restore. It does not cross my mind that he could very well pass.

Months later, I find his obituary in an area newspaper. He had passed a mere 2 weeks after leaving the hospital. He was a member of Saint Paul Catholic Church and a Vietnam War Navy veteran. His family is listed, including Mary, Matt, his siblings, grandchildren, and great-grandchildren. Interestingly, Ginny is not mentioned. A film photograph of a mischievous-looking man with dark brown hair and a wide smile accompanies the text.

I do not know the circumstances of his passing, and still know too little about this man with whom I never exchanged words. However, I am grateful to have been a witness to the power of understanding even when words are not present between a man and his family, and between a patient and a learner. 


\title{
Neurology
}

\author{
Absent Words, Present Person \\ Joan Yujae Lee \\ Neurology 2021;96;908-910 Published Online before print February 24, 2021 \\ DOI 10.1212/WNL.0000000000011758
}

This information is current as of February 24, 2021

Updated Information \& Services

Subspecialty Collections

Permissions \& Licensing

Reprints including high resolution figures, can be found at: http://n.neurology.org/content/96/19/908.full

This article, along with others on similar topics, appears in the following collection(s):

All Cerebrovascular disease/Stroke

http://n.neurology.org/cgi/collection/all_cerebrovascular_disease_strok $\mathrm{e}$

Cultural humility

http://n.neurology.org/cgi/collection/cultural_humility

Information about reproducing this article in parts (figures,tables) or in its entirety can be found online at:

http://www.neurology.org/about/about_the_journal\#permissions

Information about ordering reprints can be found online:

http://n.neurology.org/subscribers/advertise

Neurology ${ }^{\circledR}$ is the official journal of the American Academy of Neurology. Published continuously since 1951, it is now a weekly with 48 issues per year. Copyright (C 2021 American Academy of Neurology. All rights reserved. Print ISSN: 0028-3878. Online ISSN: 1526-632X.

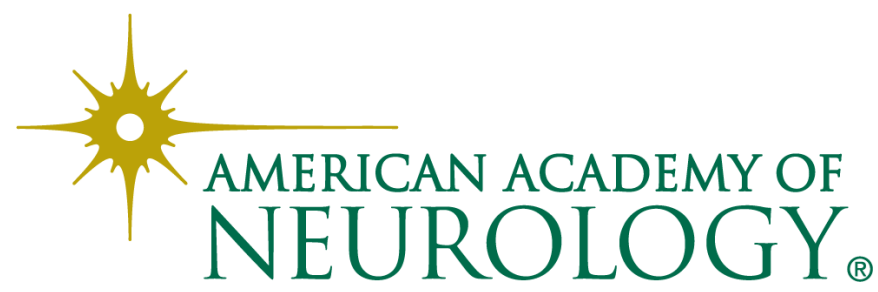

